\title{
LOCAL WISDOM: EKSISTENSI DAN DEGRADASI TINJAUAN ANTROPOLOGI SOSIAL (Ekplorasi Kearifan Lokal Etnik Ocu Di Kampar Riau)
}

\author{
Syafrizal, Ahmad Calam \\ Dosen Fakultas Ilmu Sosial Dan Ilmu Politik \\ Dosen Yayasan Program Studi Sistem Informasi, \\ Universitas Muhammadiyah Sumatera Utara dan STMIK Triguna Dharma \\ Email: syafrizal@umsu.ac.id, calamahmad72@gmail.com
}

\begin{abstract}
Abstrak
Local Wisdom (kearifan Lokal) adalah semua bentuk pengetahuan, keyakinan, pemahaman, atau wawasan serta adat kebiasaan atau etika yang menuntun perilaku manusia dalam kehidupan di dalam komunitas ekologisnya. Kearifan Lokal dapat didefinisikan sebagai kebenaran yang telah mentradisi pada suatu kawasan atau daerah, sebagai nilai yang dianggap baik dan benar yang berlangsung secara turuntemurun dan dilaksanakan oleh masyarakat yang bersangkutan sebagai akibat dari adanya interaksi antara manusia dengan lingkungannya. Secara khusus tulisan ini untuk peninjauan sekaligus menjelaskan secara antropologis sebab-sebab aspek kearifan lokal orang Ocu sebagian yang masih eksis, namun sebagiannya telah tergradasi. Proses eksplorasi aspek-aspek kearifan lokal orang Ocu, mendapati bahwa munculnya keadaan seperti itu sangat dipengaruhi oleh maksimal atau tidaknya perhubungan sosial antara orang Ocu dengan masyarakat luar akibat dilaksanakannya pembangunan transmigrasi di kawasan asal orang Ocu ini. Perbedaan besar kecil penduduk, dan besar kecilnya kekuasaan, serta besar kecilnya sumber daya manusia yang dimiliki, adalah di antara faktor utama penyebab wujunya keadaan di atas. Selain itu, diyakini telah terjadi kekosongan nilai anutan budaya pada kelompok ini. Keadaan seperti apabila didasarim oleh kondisi bahwa orang Ocu telah membuka diri (bahkan dipaksa oleh keadaan) untuk menerima nilai budaya baru, dalam waktu yang sama telah pula meninggalkan budaya asli mereka, namun penerimaan terhadap nilai budaya baru belum terseleksi yang mengakibatkan kegamangan sosial.
\end{abstract}

Kata Kunci: Kearifan Lokal, Eksistensi, Degradasi, Etnik Ocu

\section{PENDAHULUAN}

Keragaman bangsa Indonesia dari sisi etnis, suku, agama, budaya dan lainnya, sejatinya juga menunjuk kepada karaktreristik masing-masing. Budiono K (2000: 3), secara nyata keberagaman Indonesia adalah kekayaan yang tak akan pernah habis di ekploitasi sampaikapanpun juga. Pada saat yang sama, kekhasan itu pada umumnya memiliki kearifan yang pada masa-masa lalu menjadi salah satu sumber nilai dan inspirasi dalam merajut dan menapaki kehidupan mereka. Sejarah menunjukkan, masing-masing etnis dan suku memiliki kearifan lokal sendiri. Misalnya saja (untuk tidak menyebut yang ada pada seluruh suku dan etnis di Indonesia), suku Batak dikenal dengan sifatnya yang khas dengan keterbukaan, Jawa nyaris identik dengan kehalusan, suku Madura memiliki harga diri tinggi, dan etnis Cina terkenal dengan keuletan. Lebih dari itu, masing-masing memiliki keakraban, keramahan dengan lingkungan alam yang mengitari mereka.

Kearifan lokal itu tentu tidak muncul serta-merta, Syafrizal (1993), akan tetapi memerlukan proses yang cukup lama. Berbagai seleksi sosial (social selection) mesti dilalui sehingga akhirnya terbukti, hal itu mengandung kebaikan bagi kehidupan mereka. Keterujiannya dalam sisi ini membuat kearifan lokal menjadi budaya yang mentradisi, melekat kuat pada kehidupan masyarakat. Namun dari waktu ke waktu nilai-nilai luhur itu mulai meredup, memudar, kehilangan makna substantifnya. Lalu yang tertinggal hanya kulit permukaan semata, menjadi simbol yang tanpa arti. Bahkan akhir-akhir ini budaya masyarakat hampir secara keseluruhan mengalami reduksi, menampakkan diri sekadar pajangan yang sarat formalitas. Kehadirannya tak lebih untuk komersialisasi dan mengeruk keuntungan.

Banyak faktor yang membuat kearifan lokal dan budaya masyarakat secara umum, kehilangan geliat kekuatannya. Menurut Bakti Setiawan (2006), Jatna Supriatna (2008), selain kekurangmampuan masyarakat dalam memaknai secara kreatif dan kontekstual kearifan lokal mereka, faktor lainnya adalah akibat arus globalisasi, dan kepentingan subjektif dari sebagian elit masyarakat. Dari sisi etimologi, kearifan lokal (local wisdom) ini, dipahami sebagai kemampuan seseorang dengan menggunakan akal pikirannya dalam bertindak atau bersikap sebagai hasil penilaian terhadap sesuatu, objek atau peristiwa yang terjadi. Sebagai sebuah istilah wisdom kemudian diartikan sebagai kearifan/kebijaksanaan. Sementara Local secara spesifik menunjuk pada ruang interaksi terbatas dengan sistem nilai yang terbatas pula. 
Sebagai wilayah yang digunakan dalam berinteraksi dengan desain yang dibuat bersama anggota masyarakat di suatu wilayah tertentu, di dalamnya melibatkan suatu pola-pola hubungan antara manusia dengan manusia atau manusia dengan lingkungan fisiknya. Di antara pola-pola hubungan yang diperankan oleh masyarakat, yaitu: pola hubungan antar personal, dan pola hubungan antara personal dengan kelompok sosial, serta pola hubungan antara kelompok sosial dengan kelompok sosial lainnya. Pola-pola hubungan sosial yang diperankan oleh seluruh anggota masayarakat tersebut, secara langsung maupun tidak langsung akan menghasilkan berbagai aturan-aturan yang harus disepakati bersama. Pelnggaran kepada aturan tersebut akan mendapatkan sanksi sosial (social panicment), dalam bentuk peniadaan, pengurangan perhatian masyarakat kepada keberadaannya di dalam masyarakat.

Nilai-nilai tersebut yang akan menjadi landasan hubungan mereka atau menjadi acuan tingkahlaku mereka. Jim Ife (2002), menyatakan bahwa kearifan lokal merupakan nilai-nilai yang diciptakan, dikembangkan dan dipertahankan dalam masyarakat lokal dan karena kemampuannya untuk bertahan dan menjadi pedoman hidup masyarakatnya. Di dalam kearifan lokal tercakup berbagai mekanisme dan cara untuk bersikap, berprilaku dan bertindak yang dituangkan dalam tatananan sosial. Kearifan lokal merupakan semua kecerdasan-kecerdasan lokal yang ditranformasikan ke dalam cipta, karya dan karsa sehingga masyarakat dapat mandiri dalam berbagai iklim sosial yang terus berubah-ubah. Cipta, karya dan karsa itu disebut juga budaya.

Kebudayaan bukan merupakan istilah baru, namun yang dimaksudkan dengan kebudayaan adalah semua pikiran, perilaku, tindakan, dan sikap hidup yang selalu dilakukan orang setiap harinya. Proses pembudayaan atau Institusionalization adalah proses belajar yang dilalui setiap orang selama hidupnya untuk menyesuaikan diri di alam pikirannya serta sikapnya terhadap adat, sistem norma dan semua peraturan yang terdapat dalam kebudayaan dan masyarakatnnya. Dengan demikian secara umum, kearifan lokal dianggap pandangan hidup dan ilmu pengetahuan serta berbagai strategi kehidupan yang berwujud aktivitas yang dilakukan oleh masyarakat lokal dalam menjawab berbagai masalah dalam pemenuhan kebutuhan mereka.

Berbagai uraian tentang hal ehwal kearifan lokal yang dikemukkan di atas, tentunya tidak akan jauh berbeda dengan keberadaan kearifan lokal yang terdapat pada masyarakat Ocu di Kampar Riau. Secara umum, kearifan lokal pada masyarakat Kampar Riau, bermakna sebagai seperangkat pengetahuan, nilai-nilai, perilaku, serta cara bersikap terhadap objek dan peristiwa tertentu di lingkunganya yang diakui kebaikan dan kebenarannya oleh komunitas tersebut. Namun, ketegaran nilai yang menjadi anutan bahkan telah mentradisi seperti itu, mulai dihadapkan dengan realitas sosial (social reality) dalam mengimplementasikan rencana besar pembangunan nasional, yaitu polisi pembangunan transmigrasi, dengan melakukan pemindahan secara besaran-besaran orang Jawa ke berbagai daerah, karena padatnya penduduk di pulau Jawa. Salah satu tujuan pemindahan tersebut adalah di daerah Kampar Riau. Berikut ini akan kita bahas kearifan lokal yang tetap eksis dalam masyarakat Ocu Di Kampar Riau serta berbagai aspeknya.

\section{METODE PENELITIAN}

Perbincangan Tentang Orang Ocu Dan Aspek Kearifan Lokalnya

Sebagaimana dipahami, dalam beradaptasi dengan lingkungan, masyarakat memperoleh dan mengembangkan suatu kearifan yang berwujud pengetahuan atau ide, norma adat, nilai budaya, aktivitas, dan peralatan sebagai hasil abstraksi mengelola lingkungan. Seringkali pengetahuan mereka tentang lingkungan setempat dijadikan pedoman yang akurat dalam mengembangkan kehidupan di lingkungan pemukimannya. Keanekaragaman pola-pola adaptasi terhadap lingkungan hidup yang ada dalam masyarakat Indonesia yang diwariskan secara turun temurun menjadi pedoman dalam memanfaatkan sumberdaya alam. Kesadaran masyarakat untuk melestarikan lingkungan dapat ditumbuhkan secara efektif melalui pendekatan kebudayaan. Jika kesadaran tersebut dapat ditingkatkan, maka hal itu akan menjadi kekuatan yang sangat besar dalam pengelolaan lingkungan.

Perwujudan yang sama akan berlaku pula pada etnik ini. Secara umum orang Ocu adalah penduduk asli yang mendiami daerah Kampar Riau. Sebutan Ocu, diambil dari salah satu istilah tutur panggilan istimewa kepada anak keturunan keempat atau seterusnya, yaitu Acu, setelah sebutan kepada anak keturunan di atasnya. Panggilan tutur pada anak pertama adalah uwo, anak kedua adalah anga, anak ketiga adalah udo. Panggilan tutur ini sekaligus menjadi dasar dalam membentuk panggilan berikutnya akibat senioritas, perkawinan, bahkan jabatan-jabatan adat. Berkaitan dengan kebenaran asal usul orang Ocu, sememang belum diketahui secara akademik akibat ketiadaan hasil penelitian yang khas tentang etnik ini. Minimnya penelitian yang memberikan prioritas kepada penelusuran aspek-aspek identitas suatu kelompok yang secara nyata memiliki identitas keciriannya yang kemudian dapat dijadikan dasar pembeda dengan yang lain, telah disenyalir oleh para ilmuan, disebabkan oleh banyak faktor.

Pandangan yang dapat dijadikan dasar untuk menjelaskan konsep ini, sebagaimana dalam buku The Bugis (Pelras (1996: 23), menegaskan kurang atau tidak adanya hasil penelitian yang dapat dijadikan 
dasar sejarah sesebuah daerah, kelompok etnik, meskipun adanya wujud bukti berlakunya suatu keadaan secara nyata, seperti: bangunan tua, candi, dan lain. Keadaan ini dimungkin karena: (i) dampak atau impak hasil penelitian yang didapatkan dapat memberi sumbangan, apakah besar ataupun kecil kepada pengembangan ilmu pengetahuan secara umum, (ii) ketersediaan teknologi yang sesuai yang memungkinkan proses penelitian dapat dilakukan secara baik, (iii) berlakunya pelbagai perubahan semasa yang menjadikan aspek peneleitian tidak menjadi sesuatu yang penting.

Namun dari ekplorasi ke dalam secara indeep, didapatkan satu formulasi bahwa orang Ocu memiliki nenek moyang nenek moyang orang Bonai, yang telah lama ada di kawasan Kuntu, sebelum kedatangan kerajaan Sriwijaya pada abad ke-VII sebelum masehi ke kawasan Kampar. Peta ini. Setelah kedatangan kerajaan Sri Wijaya pulalah dimulainya konflik antara orang Bonai dengan orang Sri Wijaya, sehingga kekalahan dialami oleh orang Bonai, sehingga pada awalnya kelompok ini berada pada satu kawasan, akibat kekalahan tersebut kelompok ini terpencar-pencar.Situasi ini sekaligus dimulainya proses pengembaraan keberbagai kawasan, seperti: Rokan Hulu, di Bangko Jambi, di Palalawan, dan kawasan lainnya, secara nyata masih dapat ditemukan saampai sekarang ini.

Secara teoritis dalam pendekatan kebudayaan, penguatan modal sosial, seperti pranata sosialbudaya, kearifan lokal, dan norma-norma yang terkait dengan pelestarian lingkungan hidup penting menjadi basis yang utama. Adapun ciri kearifan lokal menurut Nani Norhandayani (2011) adalah: i) mampu bertahan terhadap budaya luar, ii) memiliki kemampuan mengakomodasi unsur-unsur budaya luar, iii) mempunyai kemampuan mengintegrasikan unsur budaya luar ke dalam budaya asli, iv) mempunyai kemampuan mengendalikan, v) mampu memberi arah pada perkembangan budaya. Dikemukaan pula dalam konteks fungsinya, kearifan lokal memiliki beberapa aspek pokok, di antaranya: i) untuk konservasi dan pelestarian sumberdaya alam, ii) untuk mengembangkan sumber daya manusia, iii) sebagai pengembangan kebudayaan dan ilmu pengetahuan, iv) sebagai petuah, kepercayaan, sastra dan pantangan.

Lebih jauh Nani Norhandayani (2011), menegaskan bahwa kearifan lokal selalu dihadapkan dengan berbagai tantangan berkaitan dengan perubahan zaman, maupun perkembangan tuntutan nilai kearifan lokal itu sendiri oleh pemilik atau penggunanya, seperti di bawah ini.

1. Aspek Tantangan Kearifan Lokal

a. Jumlah Penduduk, yaitu pertumbuhan penduduk yang tinggi akan mempengaruhi kebutuhan pangan dan berbagai produksi lainnya untuk mencukupi kebutuhan manusia, bahwa penduduk yang banyak merupakan penyebab kemiskinan, hal ini terjadi karena laju pertumbuhan penduduk yang mengikuti deret ukur tidak akan pernah terkejar oleh pertambahan makanan dan pakaian yang hanya mengikuti deret hitung.

b. Teknologi Modern dan Budaya, yaitu perkembangan teknologi dan ilmu pengetahuan yang cepat menyebabkan kebudayaan berubah dengan cepat pula. Perubahan yang terjadi pada masyarakat yang kebudayaannya sudah maju atau kompleks, biasanya terwujud dalam proses penemuan (discovery), penciptaan baru (invention), dan melalui proses difusi (persebaran unsur-unsur kebudayaan).

c. Modal Besar, yaitu eksploitasi terhadap sumberdaya alam dan lingkungan sekarang ini telah sampai pada titik kritis, yang menimbulkan berbagai masalah lingkungan dan masyarakat. Di samping masalah lingkungan yang terjadi di wilayah-wilayah dimana dilakukan eksploitasi sumberdaya alam, sebenarnya terdapat masalah kemanusiaan, yaitu tersingkirnya masyarakat asli (indigenous people) yang tinggal di dalam dan sekitar wilayah eksploitasi baik eksploitasi sumberdaya hutan, sumberdaya laut, maupun hasil tambang.

d. Kemiskinan dan Kesenjangan, yaitu kemiskinan dan kesenjangan merupakan salah satu masalah yang paling berpengaruh terhadap timbulnya masalah sosial. Masalah sosial yang bersumber dari kemiskinan dan kesenjangan atau kesulitan dalam pemenuhan kebutuhan pokok, sering kali tidak berdiri sendiri tetapi saling berkaitan dengan faktor lain.

Adapun jalan pemecahan yang paling mungkin untuk diambil adalah : i) mempertahankan kearifan lokal. Dalam mempertahankan eksistensinya, diperlukan suatu usaha untuk menjaganya untuk tetap berkembang dalam masyarakat. Usaha tersebut harus disertai dengan kesadaran akan peranan kearifan lokal yang sangat penting di dalam menghadapi permasalahan. Sesuai yang telah dibahas di atas, globalisasi dan westernisasi mengancam kearifan lokal. Untuk itu dalam setiap unsur asing yang masuk, hendaknya tetap memegang nilai-nilai asli sebagai pedoman ii) usulan bagi pemerintah, lebih menegakkan hukum tentang unadang-undang lingkungan hidup merupakan hal yang wajib dilakukan. Disamping itu diperlukan usaha penghijauan dan gerakan peduli lingkungan yang harus dilakukan mengingat kerusakan alam semakin parah, iii) Usulan bagi masyarakat, kesadaran, kepedulian, dan sikap tanggung jawab diperlukan dalam menjaga kelestarian lingkungan. Sadar bahwa lingkungan merupakan hal penting untuk kelangsungan hidup manusia. Peduli untuk melestarikan dan menjaga lingkungan, serta kegiatan manusia harus disertai rasa tanggung jawab terhadap alam.

2. Aspek Bentuk Kearifan Lokal 
Terdapat lebih kurang enam dimensi pokok kearifan lokal, (Jim Ife 2002), yaitu:

a. pengetahuan lokal, yaitu setiap masyarakat dimanapun berada baik di pedesaan maupun pedalaman selalu memiliki pengetahuan lokal yang terkait dengan lingkungan hidupnya. Pengetahuan lokal terkait dengan perubahan dan siklus iklim kemarau dan penghujan, jenis-jenis fauna dan flora, dan kondisi geografi, demografi, dan sosiografi. Hal ini terjadi karena masyarakat mendiami suatu daerah itu cukup lama dan telah mengalami perubahan sosial yang bervariasi menyebabkan mereka mampu beradaptasi dengan lingkungannnya. Kemampuan adaptasi ini menjadi bagian dari pengetahuan lokal mereka dalam menaklukkan alam.

b. nilai lokal, yaitu untuk mengatur kehidupan bersama antara warga masyarakat, maka setiap masyarakat memiliki aturan atau nilai-nilai lokal yang ditaati dan disepakati bersama oleh seluruh anggotannya. Nilai-nilai ini biasanya mengatur hubungan antara manusia dengan manusia, manusia dengan alam dan manusia dengan Tuhannnya. Nilai-nilai ini memiliki dimensi waktu, nilai masa lalu, masa kini dan masa datang, dan nilai ini akan mengalami perubahan sesuai dengan kemajuan masyarakatnya.

c. keterampilan lokal, yaitu kemampuan bertahan hidup (survival) dari setiap masyarakat dapat dipenuhi apabila masyarakat itu memiliki keterampilan lokal. Keterampilan lokal dari yang paling sederhana seperti berburu, meramu, bercocok tanam sampai membuat industri rumah tangga. Keterampilan lokal ini biasanya hanya cukup dan mampu memenuhi kebutuhan keluargannya masing-masing atau disebut dengan ekonomi subsisten. Keterampilan lokal ini juga bersifat keterampilan hidup (life skill), sehingga keterampilan ini sangat tergantung kepada kondisi geografi tempat dimana masyarakat itu bertempat tinggal.

d. sumber daya lokal, yaitu sumber daya lokal ini pada umumnya adalah sumber daya alam yaitu sumber daya yang tak terbarui dan yang dapat diperbarui. Masyarakat akan menggunakan sumber daya lokal sesuai dengan kebutuhannya dan tidak akan mengekpoitasi secara besar-besar atau dikomersilkan. Sumber daya lokal ini sudah dibagi peruntukannnya seperti hutan, kebun, sumber air, lahan pertanian, dan permukiman, Kepemilikan sumber daya lokal ini biasanya bersifat kolektif atau communitarian.

e. mekanisme pengambilan keputusan lokal, yaitu ahli adat dan budaya sebenarnya setiap masyarakat itu memiliki pemerintahan lokal sendiri atau disebut pemerintahan kesukuan. Suku merupakan kesatuan hukum yang memerintah warganya untuk bertindak sebagai warga masyarakat. Masing masing masyarakat mempunyai mekanisme pengambilan keputusan yang berbeda -beda. Ada masyarakat yang melakukan secara demokratis atau "duduk sama rendah berdiri sama tinggi”. Ada juga masyarakat yang melakukan secara bertingkat atau berjenjang naik dan bertangga turun.

Selain pandangan di atas, terdapat pandangan lain, bahwa kearifan lokal dapat dikategorikan ke dalam dua aspek, yaitu kearifan lokal yang berwujud nyata (tangible) dan yang tidak berwujud (intangible).

1. Kearifan lokal berwujud nyata (tangible), di antaranya adalah:

a) tekstual, yaitu beberapa jenis kearifan lokal seperti sistem nilai, tata cara, ketentuan khusus yang dituangkan ke dalam bentuk catatan tertulis seperti yang ditemui dalam kitab tradisional primbon, kalender dan prasi (budaya tulis di atas lembaran daun lontar). Sebagai contoh, prasi, secara fisik, terdiri atas bagian tulisan (naskah cerita) dan gambar (gambar ilustrasi),

b) bangunan/arsitektural, yaitu bangunan-bangunan tradisional yang merupakan cerminan dari bentuk kearifan lokal, seperti bangunan rumah rakyat di Bengkulu. Bangunan rumah rakyat ini merupakan bangunan rumah tinggal yang dibangun dan digunakan oleh sebagian besar masyarakat dengan mengacu pada rumah ketua adat. Bangunan vernakular ini mempunyai keunikan karena proses pembangunan yang mengikuti para leluhur, baik dari segi pengetahuan maupun metodenya. Bangunan vernacular ini terlihat tidak sepenuhnya didukung oleh prinsip dan teori bangunan yang memadai, namun secara teori terbukti mempunyai potensi-potensi lokal karena dibangun melalui proses trial \& error, termasuk dalam menyikapi kondisi lingkungannya,

c) benda cagar budaya/tradisional (karya seni) Benda-benda cagar budaya yang merupakan salah satu bentuk kearifan lokal, contohnya, keris. Keris merupakan salah satu bentuk warisan budaya yang sangat penting. Meskipun pada saat ini keris sedang menghadapi berbagai dilemma dalam pengembangan serta dalam menyumbangkan kebaikan-kebaikan yang terkandung di dalamnya kepada nilai-nilai kemanusiaan di muka Bumi ini, organisasi bidang pendidikan dan kebudayaan atau UNESCO Badan Perserikatan Bangsa Bangsa, mengukuhkan keris Indonesia sebagai karya agung warisan kebudayaan milik seluruh bangsa di dunia. Setidaknya sejak abad ke-9, sebagai sebuah dimensi budaya, Keris tidak hanya berfungsi sebagai alat beladiri, namun sering kali merupakan media ekspresi berkesenian dalam hal konsep, bentuk, dekorasi hingga makna yang terkandung dalam aspek seni dan tradisi teknologi arkeometalurgi. Keris memiliki fungsi sebagai seni simbol jika dilihat dari aspek seni dan merupakan 
perlambang dari pesan sang empu penciptanya. Ilustrasi lainnya adalah batik, sebagai salah satu kerajinan yang memiliki nilai seni tinggi dan telah menjadi bagian dari budaya Indonesia (khususnya Jawa) sejak lama. Terdapat berbagai macam motif batik yang setiap motif tersebut mempunyai makna tersendiri. Sentuhan seni budaya yang terlukiskan pada batik tersebut bukan hanya lukisan gambar semata, namun memiliki makna dari leluhur terdahulu, seperti pencerminan agama (Hindu atau Budha), nilai-nilai sosial dan budaya yang melekat pada kehidupan masyarakat.

2. Kearifan lokal berwujud tidak nyata (intangible), seperti petuah yang disampaikan secara verbal dan turun temurun yang dapat berupa nyanyian dan kidung yang mengandung nilai-nilai ajaran tradisional. Melalui petuah atau bentuk kearifan lokal yang tidak berwujud lainnya, nilai sosial disampaikan secara oral/verbal dari generasi ke generasi. Kearifan lokal berwujud tidak nyata, misalnya: a) Papua, terdapat kepercayaan te aro neweak lako (alam adalah aku). Gunung Erstberg dan Grasberg dipercaya sebagai kepala mama, tanah dianggap sebagai bagian dari hidup manusia. Pemanfaatan sumber daya dilakukan secara seksama dan secara hati-hati. b) Serawai, Bengkulu, terdapat keyakinan celako kumali. Kelestarian lingkungan terwujud dari kuatnya keyakinan ini yaitu tata nilai tabu dalam berladang dan tradisi tanam tanjak. c) Dayak Kenyah, Kalimantan Timur, terdapat tradisi tana ' ulen. Kawasan hutan dikuasai dan menjadi milik masyarakat adat. Pengelolaan tanah diatur dan dilindungi oleh aturan adat. d) Masyarakat Undau Mau, Kalimantan Barat. Masyarakat ini mengembangkan kearifan lingkungan dalam pola penataan ruang pemukiman, dengan mengklasifikasi hutan dan memanfaatkannya. Perladangan dilakukan dengan rotasi dengan menetapkan masa bera, dan mereka mengenal tabu sehingga penggunaan teknologi dibatasi pada teknologi pertanian sederhana dan ramah lingkungan, e) Masyarakat Kasepuhan Pancer Pangawinan, Kampung Dukuh Jawa Barat. Mereka mengenal upacara tradisional, mitos, tabu, sehingga pemanfaatan hutan hati-hati. Tidak diperbolehkan eksploitasi kecuali atas ijin sesepuh adat, f) Bali dan Lombok, masyarakat mempunyai awig-awig.

\section{PEMBAHASAN DAN HASIL PENELITIAN}

Kearifan Lokal Suatu Ekplorasi

1. Hasil ekplorasi kearifan lokal yang masih terpelihatra

Melihat keterkaitan yang demikian kuat antara kearifan lokal dengan nilai atau norma yang dalam proses kehidupan sosial di dalam masyarakat, terutama berkaitan dengan tujuan yang hendak dicapai. Secara praktikal adat dan norma adat memiliki tujuannya yang amat pokok, iaitu untuk menciptakan perhubungan sosial yang harmoni dalam masyarakat. Pernyaan di atas sejalan dengan pandangan Sills (1968: 284), iaitu: ".... a rule or standard of behavior defined by the shared expectation of two or more people regarding what behaviour is to be considered socially acceptable. A norm in this sense is not a statistical average of actual behaviour but rather a culture (shared) definition of desreable behavior....". Menurut Syafrizal (1993), ragam kearifan lokal etnik Ocu, sesungguhnya adalah kandungan nilai dan norma adat (pantang larang) yang menjadi pengamalan harian orang Ocu.

Klarifikasi tentang keberadaannya, dapat dilihat dari keterpakaian atau ketidakketerpakaian aspek kearifan lokal tersebut di dalam agenda-agenda penting orang Ocu, maupun dalam praktek hubungan sosialnya. Selain hal di atas, secara umum terdapat beberapa sumber nilai dan norma yang menjadi pedoman hidup etnik Ocu (orang $\mathrm{Ocu}$ ) yang ikut memelihara proses kehidupan sehari-hari. Aspek-aspek itu adalah: (i) sobanau ade' yang dimaknakan sebagai adat sebenar. Adat sebenar yang menunjuk kepada asas sebenar semulajadi, seperti adat air membasahi, adat murai berkicau, adat api membakar dan sebagainya, (ii) ade' nandiade'kan, yang dimaknakan sebagai adat yang diadatkan, iaitu adat kebiasaan kumpulan orang Ocu yang dianggap benar, oleh itu diturunkan kepada anak cucu secara turun temurun.

Diperkirakan adat semacam ini ditubuhkan oleh kumpulan bersendiri mengikut pengalaman sejak lama dari nenek moyang terdahulu, (iii) ade' nan ta ade', yang dimaknakan sebagai kebiasaan yang mentradisi di dalam kumpulan orang Ocu, seperti kebiasaan bersuonghang, pacendo, mambonto, puasan, balimaukasai, dan lainnya. Kemudian dalam prakteknya seluruh aspek nilai dan norma adat Ocu di atas, terjelma di dalam praktek keseharian masyarakatnya. Pelanggaran terhadap nilai dan norma tersebut akan mendapatkan sanksi adat, seperti uraian di bawah ini.

\begin{tabular}{|l|l|l|}
\hline NO & \multicolumn{1}{|c|}{\begin{tabular}{c}
\multicolumn{1}{|c|}{$\begin{array}{c}\text { Kearifan Lokal } \\
\text { Aspek Kemasyarakatan }\end{array}$} \\
\hline 1
\end{tabular} a. badondong (nyanyian porno) } & $\begin{array}{l}\text { Sanksi Adat } \\
\text { dicela sebagai manusia yang tiada beradat dan } \\
\text { tiada bermoral }\end{array}$ \\
\hline 2 & $\begin{array}{l}\text { b. batutan sumondan (berkawin dalam satu } \\
\text { suku) }\end{array}$ & $\begin{array}{l}\text { perkahwinan terlarang, dilarang mukim di } \\
\text { kampung asal. }\end{array}$ \\
\hline 3 & $\begin{array}{l}\text { c. anak gampang (berzina) } \\
\text { dicela dan dilarang mukim di kampung asal, } \\
\text { diingati, sebagai keburukan keluarga (ta coreng }\end{array}$ \\
\hline
\end{tabular}




\begin{tabular}{|c|c|c|}
\hline & & aghang di koniong) \\
\hline & II. Aspek Keluarga & sanksi adat \\
\hline 1 & $\begin{array}{llll}\text { a. } & \begin{array}{l}\text { cacawik atau } \\
\text { (bercakapporno) }\end{array} & \text { ba cawik }\end{array}$ & $\begin{array}{l}\text { dianggap manusia tiada sopan santun dan tiada } \\
\text { bermoral }\end{array}$ \\
\hline 2 & b. soghaw (suka memfitnah) & $\begin{array}{l}\text { dianggap penjahat, tidak disukai orang untuk } \\
\text { berkawan akibat dicela, keluarga memperolehi } \\
\text { aib. }\end{array}$ \\
\hline 3 & $\begin{array}{l}\text { c. berperilaku banci (lelaki menjadi } \\
\text { perempuan dan sebaliknya) }\end{array}$ & $\begin{array}{l}\text { Dipandang sebelah mata, bermakna dicela, } \\
\text { keluarga memperolehi aib. }\end{array}$ \\
\hline
\end{tabular}

Secara terperinci, dikemukakan aspek-aspek kearifan lokal etnik Ocu, yang masih terpelihara keeksistensiannya maupun yang telah terdegradasi oleh berbagai penyebab, berikut ini.

1. Kearifan Lokal Yang Dianggap Masih Terpelihara (eksis)

a. Gotong Royong yaitu bekerja sama dalam berbagai hal yang sifatnya keummatan, seperti membangun rumah ibadah, kemalangan atau kematian, pemeliharaan anak yatim dan lainnya.

b. Langkah-langakah atau proses perkawinan

c. Hubungan kekerabatan yang mengikuti garis keturunan nasab Ibu.

d. Penghargaan terhadap nilai-nilai adat yang bekaitan dengan hubungan sesama anggota masyarakat bahkan dengan kelompok lain.

e. Adat sopan santun, terutama berkaitan dengan hubungan keluarga.

2. Kearifan Lokal Yang Dianggap Telah Mengalami Kemunduran Atau Semakin Hilang (terdegradasi).

a) Tanah tenggi (bukik, koto tenggi), yaitu bagian tanah terpilih dan ditetapkan melalui mekanisme adat, yang tidak boleh di miliki bahkan dimanfaatkan untuk kepentingan perseorangan, untuk menjawab tantangan alam yang sudah diprediksi akan senantiasa terjadi. Pemilihan dan penetapan kawasan ini kepada larangan untuk dimanfaatkan untuk diusahakan bahkan dialih fungsikan, memiliki fungsi pemecahan masalah (problem solving) saat seluruh masyarakat tidak memiliki pilihan untuh bertahan hidup dari ancaman alam, seperti banjir bandang. Namun setelah dibangun bendungan pembangkit tenaga listrik (PLTA) Koto Panjang, volume air dapat dikontrol, sehingga banjir musiman dapat dikelola dengan baik.

b) Ghimbo laghangan (ghimbo ulayat), yaitu kawasan hutan yang diperuntukan untuk konservasi atau cadangan kehidupan anak cucu. Ghimbo laghangan dikawal dan hanya boleh dimanfaatkan oleh warga suku atau beberapa suku tertentu. Biasanya penggunaan ghimbo laghangan ini untuk meramu kayu untuk mendirikan rumah masyarakat, mamikek kuaghan, manjoghek binatang pedaging. Ghimbo laghangan tidak selalu diabadikan sebagai penanda eksisnya kesukuan tertentu atau beberapa kesukuan tertentu.

c) Ponakan malokok (kaponakan tali akaw), yaitu kearifan lokal yang memungkinkan orang lain yang bukan anggota etnik, untuk dapat diterima secara bersungguhan di dalam keluarga Ocu. Ponakan malokok adalah ponakan yang diangkat oleh keluarga akibat telah dinilai dan telah lama menunjukkan kebaikan kepada keluarga. Agar seseorang yang telah menunjukkan kebaikan tersebut, adat istiadat Ocu memberikan peluang seseorang itu menjadi bagian penting keluarga tersebut, dengan memberikan jaminan keselamatan, perlindungan adat, serta berbagai hak dan kewajiban yang harus dilaksanakan.

d) Pambotuong, yaitu cara pembagian air dipersawahan dengan menggunakan teknologi sederhana yang diciptakan oleh masyarakat sendiri. Pada sebagian daerah yang ada persawahan, kearifan lokal semacam ini masih dapat ditemukan.

e) Canang (kalintuong, gonto-gonto), yaitu peralatan sederhana yang digunakan sejak lama oleh etnik Ocu untuk mengkhabarkan sesuatu yang dianggap penting untuk diketahui, diikuti dan ditaati oleh seluruh masyarakat. Biasanya dilakukan oleh petugas yang dibentuk untuk keperluan, isi pesan yang akan disampaikan benar-benar tepat, dengan berkeliling kampung dalam waktuyang cukup lama. Bagi etnik Ocu, apabila terdengar bunyi canang atau kalintuong, secara spontan masyarakat akan keluar rumah beramai-ramai untuk memastikan isi pesan yang disampaikan, bahkan sebagian dari kaum muda akan ikut iringan pencanang sehingga menjadi ramai. Namun, sekarang ini kearifan lokal seperti ini sudah tergantikan oleh kemajuan teknologi.

f) Balimau kasai, yaitu aktivitas mandi di sungai, ataupun di rumah, sendiri-sendiri atau bersama-sama. Pada awalanya aktivitas balimau kasai sebagai suatu ritual yang murni, yaitu 
mandi membersihkan badan sebelum bulan ramadhan tiba. Akan tetapi terjadi pergeseran, aktiviti balimau kasai dipahami sebagai suatu aktivitas yang dilakukan secara kolosal ditepi sungai, dengan penambahan berbagai aktivitas lainnya, seperti: musik, pekan jualbeli, berkemah, dan lain sebagainya.

g) Larangan perkawinan se-suku (melanggar sumpah, penyakitan, dikucilkan), yaitu dianggap perkawinan terlangan (inces) apabila dilakukan perkawinan se-suku, dianggap melanggar sumpah. Pelanggaran sumpah tersebut akan dipercayai akan terkena penyakit memalukan, semisal: kurap disekujur tubuh, anak yang lahir tidak normal atau cacat, serta akan dianggap tidak ada di dalam pergaulan masyarakat. Sebagai etnik yang sangat konsen dengan nilai dan norma adat, orang ayang kawin se-suku tentunya tidak akan mendapatkan gelaran adat, sehingga mereka akan terkucilkan bahkan terhina dalam masyarakat etnik Ocu.

h) Ladang guru (meladangkan guru), yaitu melakukan gotong royong dalam mengerjakan sawah meladang guru (terutama guru mengaji) yang dilakukan oleh orang tua murid, bahkan seluruh anggota masyarakat. Aktivitas seperti ini menjadi kelaziman dalam etnik Ocu, tanpa diminta oleh pihak guru akan tetapi secara spontan bila musim ke sawah dan ladang tiba. Aktivitas ladang guru ini, dilakukan dari sejak awal pengusahaan ladang sawah, sampai dengan musim panen (pengambilan hasil padi di sawah ladang), bahkan sampai padi menjadi beras. Dapat diyakini proses ladang guru ini, memiliki nilai yang sangat mulia. Paling tidak terdapat beberapa hal yang terkandung di dalamnya, yaitu: i) ucapan terima kasih kepada jasa guru yang mengajar mengaji, mengajar melaksanakan sholah dan pengajaran tentang berbagai hukum agama tentang pantang larangnya, 2) suatu wujud penghormatan kepada guru. Aktivitas ladang guru ini pada sebagian besar daerah tidak lagi dijumpai, namun dibeberapa daerah pedalaman Kampar masih ada dengan pola yang sudah disesuaikan.

i) Silio (nyilio, manyilio), yaitu proses barteran terhadap berbagai bentuk benda atau barang di antara anggota masyarakat. Adapaun bentuk barang silioan tersebut dapat berupa bahanbahan untuk membangun rumah (kayu, atap, bahkan bahan-bahan satu buah rumah). Akan tetapi barang-barang silio yang lazim dilakukan harian adalah bahan-bahan makanan akibat kekurangan sebelum hari pasar tiba. Hari pasar biasanya hanya satu kali dalam seminggu. Kearifan lokal semacam ini mempunyai maknanya yan sangat strategis, bukan saja dilihat dari aspek saling memberi dan menerima bahan-bahan silio-annya, namun dapat diartikan demikian terpelihara rasa kebersamaan, persaudaraan dalam masyarakat. Namun, melihat realitas sosial sekarang ini, hal demikian ini jarang terjadi, bahakan telah semakin pupus akibat munculnya egosentris di antara anggota masyarakat. Hubungan sosial antara satu keluargapun atau adik beradikpun sekarang ini penuh dengan konflik, sehingga nilai-nilai seperti yang dikemukakan di atas semakin hilang dalam praktek hidup sehari-hari orang Ocu.

j) Batobo, yaitu semacam arisan pengolahan sawah ladang yang dikerjakan secara bergantian. Batobo adalah salah satu aspek yang paling pokok mencirikan kelompok ini. Batobo dianggap sebagai identitas yang membedakan dengan kelompok lain.

k) Bamacang basampuok, yaitu proses yang dilakukan secara sadar dan memiliki makna yang amat mendalam dengan melakukan kegiatan bamacang basampuok untuk memperlancar pekerjaan di sawah dan ladang, sekaligus proses untuk mendapatkan laki-laki atau perempuan idaman untuk di jadikan jodoh (suami istri).

1) Badondong, yaitu nyanyian yang dianggap sakral atau tabu, pantang larang apabila dilaukan disembarangan waktu atau tempat. Badondong juga termasuk pencirian yang utama orang Ocu dengan orang lain. Apabila seseorang bertanya apakah ia orang Ocu ataupun tidak, selalu dengan menjawab atau melakukan badondong, maka hal itu memastikan dia adalah orang Ocu.

\section{KESIMPULAN}

Penganalisaan secara teoritis bahwa setiap kelompok etnik memiliki kearifan lokal sendiri. Kepemilikan kearifan lokal ini berawal dari proses interarksi suatu kepompok etnik tersebut dengan kehidupan dimana mereka berada. Pola interaksi sesama mereka dan dipertajam oleh pola lain apabila berhubungan dengan kelompok etnik lainnya, dalam masa yang lama, secara terus menerus. Selain itu, perilaku dan pola hubungan suatu kelompok dengan alam sekitarnya, yang diazazkan oleh oleh pola laku penghambaan mereka terhadap sang pencipta, terhadap apa yang dipercayai dan diyakini. Salah satu aspek kearifan lokal yang paling mudah diketahui adalah berbagai pola lau keseharian yang ditunjukkan oleh kelompok masyarakat yang dianggap menjadi ciri khas kelompok bersangkutan. Katakan saja suku Batak kental dengan keterbukaan, Jawa nyaris identik dengan kehalusan, suku Madura memiliki harga 
diri yang tinggi, dan etnis Cina terkenal dengan keuletan. Lebih dari itu, masing-masing memiliki keakraban dan keramahan dengan lingkungan alam yang mengitari mereka.

Namun, secara praktis, dapat dikemukakan bahawa keberagaman kearifan lokal yang terdapat pada setiap kelompok etnik, memiliki segi-segi kesamaan tujuan yang ingin dicapai, memiliki tantangan yang sama yaitu tantangan yang datang dari internal kelompoknya, maupun yang bdatang dari eksternal kelompoknya. Selain itu, secara praktikal kearifan lokal yang ada pada setiap kelompok etnik, sedang dan selalu akan berhadapan proses degradasi akibat multi kondisi, yang bersumber kepada berbagai inovasi ilmu pengetahuan dan tekhnologi yang semakin berkembangan.

Akan demikian pula dengan kelompok orang Ocu, sebagaimana yang diketengah dalam penguraian di atas. Hasil eksplorasi terhadap ciri, bentuk, serta tantangan terhadap kearifan lokal etnik ini, secara nyata dapat diklasifikasi ke dalam dua bentuk, yaitu: i) kearifan lokal pada kelompok etnik Ocu tidak lagi dijadikan satu-satunya dasar berpijak oleh komunitas ini, bahkan nilai kearifan yang dimiliki oleh kelompok sendiri tidak dipakai di dalam mengatur proses kehidupan sehari-hari secara berkelompok. ii) proses degradasi aspek kearifan lokal orang Ocu sesungguhnya telah berlangsung lama, namun tidak ada kepedulian kelompok untuk mengambil langkah-langkah preventif (pencegahan) maupun kuratif (pengobatan, atau perbaikan). iii) Terdapat beberapa aspek kearifan lokal orang Ocu antara masih terpelihara, akan tetapi bersifat parsial. Hal ini disebabkan karena kearifan lokal seperti telah menjadi koleksi budaya pihak berkepentingan seperti pemerintah. Namun secara nyata kearifan lokal seperti itu tidak ditemukan lagai dalam aktivitas anggota masyarakat seharian.

Oleh karena itu, berbagai proses negatif sering terjadi baik di antara sesama orang Ocu bahkan dalam keluaarga sendiri, maupun di dalam proses menjalankan interaksi sosial dengan kelompok lain. Kecenderungan ini, dapat terjadi akibat terjadinya kekosongan nilai dan norma mana ayang harus diikuti secara berkumpulan, nilai dan norma yang lama telah mulai ditinggalkan sedangkan nilai dan norma yang baru belum terseleksi secara baik tentang benar salah, sesuai atau tidak sesuainya dengan alam pemikiran orang secara berkelompok. Gambaran ini, sesungguhnya berkaitan erat dengan kedatangan orang Jawa yang menjadi transmigrasi di kawasan ini. Kekosongan nilai akibat mencoba menerima nilai budaya baru dari kelompok pendatang orang Jawa, bahkan dapat diduga akibat ketidakberdayaan orang Ocu untuk melawan ekuatan budaya orang Jawa sebagai peserta transmigrasi, adalah bahagian yang pantas diperbincangan lebih jauh. Sungguh keadaan ini menjadi titik kemunduran kelompok ini, untuk tetap menjadi kelompok yang eksis dengan warna dan ragam budaya kearifan lokalnya sendiri.

\section{DAFTAR PUSTAKA}

Bakti Setiawan, 2006. Jatna Supriatna, 2008, Pembangunan Berkelanjutan dan Kearifan Lingkungan. Dari Ide Ke Gerakan, PPLH Regional Jawa, Kementerian Negara Lingkungan Hidup RI, Yogyakarta.

Budiono K. 2000. Kebhinnekaan Masyarakat Indonesia, Suatu Problema Filsafat di Indonesia. Jakarta: Gramedia Widiasarana Indonesia.

Francis Wahono, 2005. Pangan, Kearifan Lokal dan Keanekaragaman Hayati, Penerbit Cindelaras Pustaka Rakyat Cerdas, Yogyakarta Gunggung Seno Aji, 2003.

Nani Norhandayani. 2011. Pengertian Kearifan Lokal. http://naninorhandayani.blogspot.my/2011/05/pengertian-kearifan-lokal.html

Siti Wahyuni. 2014. Kearifan-Lokal. https://nadjaneruda.wordpress.com/2014/07/07/kearifan-lokal/ (23.56 pm) siti wahyuni.

Wilda. 2015. Hubungan Kearifan Lokal Dengan Kebudayaan. https://wildawilda.wordpress.com/2015/09/08/hubungan-kearifan-lokal-dengan-kebudayaan/ (00.03 am) wildawilda.

Ife, Jim \& Frank Tesoriero. 2008. Community Development. (Terj. S. Manullang, dkk: PustakaPelajar.https://www.academia.edu/7699147/Pegunungan_Kendeng_Utara_Sedulur_Sike p_Kearifan_Lokal_dan_Advokasi_Kebijakan_Publik.

Pelras, C. 1996. The Bugis. Blackwell Publishers Limited, Oxford. (pnyt). Abdul Rahman Abu. 2006. Manusia Bugis. Jakarta: Nalar.

Sills, David, L. 1968. International Encyklopedia of the Social Sciences. Dlm. Rukmadi. Warsito. et. All. 1984 (pnyt). Transmigrasi Dari Daerah Asal Sampai Benturan Budaya Di Tempat Pemukiman. CV. Rajawali. Jakarta.

Syafrizal. 1993. Ungkapan-Ungakan Tradisional Masyarakat Rumbio. UNRI. Pekanbarau. 